2016-07-30

\title{
Global Insights and Support
}

\author{
Lynch, TJ
}

http://hdl.handle.net/10026.1/6376

10.1007/978-3-319-31667-3_6

Springer International Publishing

All content in PEARL is protected by copyright law. Author manuscripts are made available in accordance with publisher policies. Please cite only the published version using the details provided on the item record or document. In the absence of an open licence (e.g. Creative Commons), permissions for further reuse of content should be sought from the publisher or author. 


\title{
Global Insights and Support
}

\begin{abstract}
This chapter shares a deeper analysis of insights from the UK case study research, which indicated that partnership complexities were minimised when the relationships were developed over a sustained period of time, where genuine trust is built between stakeholders and not forced. Furthermore, when learning created through partnerships were perceived as relevant by all stakeholders, there was some form of funding, and teacher educators were confident and competent with the children aged 5-11 years. These insights were supported by recent shifts in teacher education. Hence, the global insights offered timely support and direction for the 'Best Start' programme.
\end{abstract}

This international case study investigated quality Initial Teacher Education (ITE) (physical education) also referred to as Quality Physical Education Teacher Education (QPETE). The ITE programme was identified as having strong partnerships with local schools by England's Office for Standards in Education (Ofsted) and external examiners which were evidenced during data collection. A deeper intention of the case study was to explore partnerships for possible 'hybrid space' course features.

(C) The Editor(s) (if applicable) and The Author(s) 2016

T. Lynch, The Future of Health, Wellbeing and Physical Education, DOI 10.1007/978-3-319-31667-3_6 
ment skills naturally; rather, they need to be provided with quality learning experiences to enable development (Doorn 1999).

Only Case Study Two school lessons observed by the researcher actually confirmed the teacher participants' shared insights and evidenced their understanding of the socio-cultural approach, embedded in the HPE syllabus. This was evidenced through the promotion of social justice and equity principles, where the HPE specialist teacher structured and taught inclusive lessons which acknowledged student diversity and skill levels and created supportive learning environments (QSCC 1999). Such learning environments were created through the use of eclectic pedagogies. At times, a traditional dominant science pedagogy (Tinning 2004) was evidenced with emphasis placed on correct skills and movement techniques. This was achieved through demonstrations, cues, explanations, and by providing feedback to students. At other times, critical socially just pedagogies (Tinning 2004) were evidenced in a diverse range of sports and skills covered and implemented using several minor games simultaneously, enabling students maximum participation and involvement. (ie. Lynch, 2005, pp. 241-242).

The research findings and insights from the UK ITE case study were embedded within the HPS framework. Furthermore, when combined with the data gathered from Australian primary school principals and recent shifts in Teacher Education, such as the Victorian Government 'School Centres for Teaching Excellence' (SCTE) initiative, the global insights offered welcome and timely support along with direction for the 'Best Start' programme leader.

\section{REFERENCES}

Australian Curriculum, Assessment and Reporting Authority. (2012). Draft shape of the Australian curriculum: Health and physical education. Retrieved from http://www.acara.edu.au/hpe.html

Australian Health Promoting Schools Association. (1996). The health promoting school framework. In Deakin University (Ed.), The health promoting schoolReader (pp. 1-7). Geelong, VIC: Deakin Print Services.

Baumgartner, F., Koerner, M., \& Rust, F. (2002). Exploring roles in student teaching placements. Teacher Education Quarterly, 29, 35-58.

Centre for Primary Education. (1998). Health promoting schools. The Primary Educator, 4(5), 1-4.

Commonwealth of Australia. (1992). Physical and sport education-A report by the senate standing committee on environment, recreation and the arts. Canberra, ACT: Senate Printing Unit. 
Darling-Hammond, L. (2006). Constructing 21st-century teacher education. Journal of Teacher Education, 57, 1-15.

Denton, J. J. (1982). Early field experience influence on performance in subsequent coursework. Journal of Teacher Education, 33(2), 19-23.

Dinan-Thompson, M. (2009). Health and physical education: Issues for curriculum in Australia and New Zealand. South Melbourne, VIC: Oxford University Press.

Doorn, P. (1999). Is your PDHPE program fundamentally sound? Curriculum Support for Primary Teachers, 4(3), 3-4.

Douglas, A. (2014). Student teachers in school practice. Hampshire: Palgrave MacMillan.

Graham, G., Holt-Hale, S. A., \& Parker, M. (1998). Children moving-A reflective approach to teaching physical education (4th ed.). Mountain View, CA: Mayfield.

Howard, J. (2004, June 29). Building a bealthy, active Australia. Transcript of the launch by Prime Minister, John Howard. Launceston, Tasmania. Retrieved January 7, 2005, from Building a Healthy, Active Australia Launch Launceston, Tasmania Web site: www.pm.gov.au/news/speeches/speech961.html

Lynch, T. (2005). An evaluation of school responses to the introduction of the Queensland 1999 bealth and physical education (HPE) syllabus and policy developments in three Brisbane Catholic primary schools (Doctoral thesis, ACU National, Australia). Retrieved from http://dlibrary.acu.edu.au/digitaltheses / public/adt-acuvp96.04092006/02whole.pdf

Lynch, T. (2013c). School centers for teaching excellence (SCTE): Understanding new directions for schools and universities in health and physical education. Asia-Pacific Journal of Health, Sport and Physical Education, 4(3), 249-266. DOI:10.1080/18377122.2013.836770

Lynch, T. (2013d). Summary report of key findings for Australian Government primary schools. How are primary Education, Health and Physical education (HPE) teacher's best prepared? Retrieved from http://www.aitsl.edu.au/docs/ default-source/default-document-library/lynch_2013_preparation_of_primary_health_physical_education_teachers.pdf?sfvrsn $=4$

Lynch, T. (2015). Health and physical education (HPE): Implementation in primary schools. International Journal of Educational Research, 70(c), 88-100. doi:10.1016/j.ijer.2015.02.003.

Macdonald, D. (2013). The new Australian Health and Physical Education Curriculum: A case of/for gradualism in curriculum reform? Asia-Pacific Journal of Health, Sport and Physical Education, 4(2), 95-108.

Martin, S. D., Snow, J. L., \& Franklin Torrez, C. A. (2011). Navigating the terrain of third space: Tensions with/in relationships in school-university partnerships. Journal of Teacher Education, 62(3), 299-311. 
Medland, A., \& Taggart, A. (1993, November). The implementation of a health related fitness intervention: A case study of two primary schools. Paper presented at the Australian Association for Research in Education Conference, Fremantle, WA.

Murray, J. (2010). Towards a new language of scholarship in teacher educators' professional learning? Professional Development in Education, 36(1-2), 197-209.

National Association for Sport and Physical Education. (2008). Advanced standards for physical education. Retrieved from http://www.shapeamerica.org/ accreditation/upload/Advanced-2008-PETE-Standards.pdf

O'Dea, J., \& Maloney, D. (2000). Preventing eating and body image problems in children and adolescents using the health promoting schools, framework. Journal of School Health, 70(1), 18-21.

Olrich, T. (2002). Assessing fundamental motor skills in the elementary school setting: Issues and solutions. Journal of Physical Education, Recreation and Dance, 73(7), 26-32.

Queensland Government. (2003). Get active Queensland, early childhood resources. Brisbane, QLD: Queensland Government Printer.

Queensland School Curriculum Council. (1999). Health and physical education initial in-service materials. Brisbane, QLD: Publishing Services, Educational Queensland.

Saltmarsh, N. R. (2001, August 4). Fitness; better role models, community involvement could make obese kids fitter. Health and Medicine Week, 12-13. Atlanta.

Teacher Education Ministerial Advisory Group (TEMAG). (2014). Action now: Classroom ready teachers. Retrieved from http://www.studentsfirst.gov.au/ teacher-education-ministerial-advisory-group

Tinning, R. (2004). Rethinking the preparation of HPE teachers: Ruminations on knowledge, identity, and ways of thinking. Asia-Pacific Journal of Teacher Education, 32(3), 241-253.

Webster, P. J. (2001). Teachers' perceptions of physical education within the k-6 personal development, health and physical education key learning area (Theses, University of Woollongong). Abstract retrieved June 28, 2004, from Informit database.

World Health Organisation. (1994). Life skills education in schools-division of mental health. Manila: Author.

World Health Organisation. (1996). Health promoting schools: Regional guidelines development of health-promoting schools-A framework for action-Regional Office, Western Pacific. Manila: Author.

Zeichner, K. (2010). Rethinking the connections between campus courses and field experiences in college and university-based teacher education. Journal of Teacher Education, 61(1-2), 89-99. 